\title{
Orbital myositis presenting with only unilateral orbital pain
}

\author{
Saori Utsunomiya, Daisuke Yamamoto, Tsuyoshi Uchiyama
}

Department of Neurology, Seirei Hamamatsu General Hospital, Hamamatsu, Japan

Correspondence to Dr Daisuke Yamamoto, daisuke-yama@sis.seirei.or.jp

Accepted 17 May 2017

\section{DESCRIPTION}

A 24-year-old woman developed sudden severe periorbital pain characterised by severe, unilateral, pounding, short-lived, repetitive pain. Consequently, she was diagnosed with paroxysmal haemicrania at the first visit. There was no history of diplopia or other ophthalmic symptoms. Her physical and other neurological findings were normal. Anti-thyroid and antinuclear antibodies were negative. IgG4, soluble interleukin-2 receptor, C-reactive protein and creatine kinase levels; cerebrospinal fluid analysis; and CT scan were normal. MRI revealed enlargement and increased signal in the left medial rectus muscle on gadolinium-enhanced T1-weighted imaging suggesting orbital myositis $(\mathrm{OM})$ (figure 1A,B). The patient was treated with three cycles of intravenous methylprednisolone (IVMP) followed by oral prednisolone $30 \mathrm{mg} /$ day, resulting in rapid resolution of the symptoms. There was no relapse after reducing the prednisolone dosage, and MRI findings were almost resolved after 2 months of steroid therapy (figure 1C,D). The most frequently used medication of OM is oral corticosteroid, and IVMP has been effectively used in some patients. ${ }^{1} \mathrm{OM}$

\section{Learning points}

- Orbital myositis is classically characterised by acute-onset orbital pain often accompanied with ophthalmic symptoms (eg, diplopia, ptosis, chemosis and conjunctival injection); however, orbital myositis could develop only severe orbital pain.

- Orbital myositis could mimic symptoms of paroxysmal haemicrania or cluster headache.

- An MRI of the orbit is helpful for diagnosing orbital myositis with atypical symptoms.

is an idiopathic non-infectious inflammatory disease primarily involving extraocular muscles, characterised by acute-onset orbital pain often accompanied with diplopia, ptosis, chemosis and conjunctival injection. ${ }^{12}$ The present case demonstrated only orbital pain, and symptoms mimicked paroxysmal haemicrania. A similar case of OM, misdiagnosed as cluster headache, has been reported. ${ }^{3}$ An MRI scan of the orbit is a diagnostic tool for OM. It is unusual that $\mathrm{OM}$ showed only orbital pain without
To cite: Utsunomiya $S$, Yamamoto D, Uchiyama T. BMJ Case Rep Published Online First: [please include Day Month Year]. doi:10.1136/bcr-2017220615

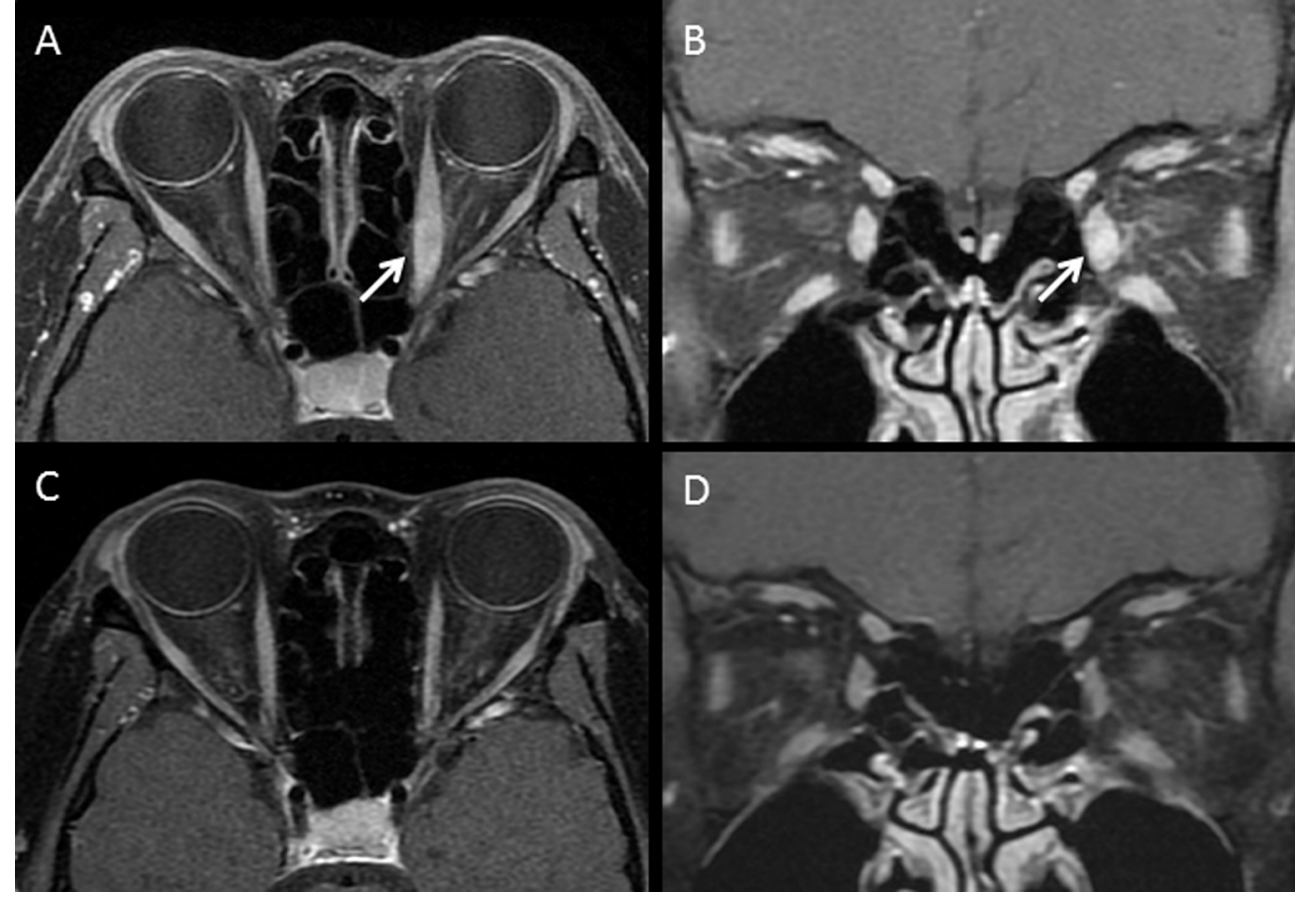

Figure 1 ( $A, B)$ Brain MRI at admission reveals enlargement and increased signal with enhancement in the left medial rectus muscle on gadolinium-enhanced T1-weighted imaging (arrow). (C, D) Brain MRI reveals significant improvement on gadolinium-enhanced T1-weighted imaging after 2 months of steroid therapy. 
other ophthalmic symptoms; however, we should consider the possibility of OM in such a setting, and MRI would be helpful in the diagnosis process.

Contributors SU was a major contributor in writing the manuscript. TU and DY also treated the patient and interpreted the patient data. All authors read and approved the final manuscript.

Competing interests None declared.

Patient consent Obtained.

Provenance and peer review Not commissioned; externally peer reviewed. (c) BMJ Publishing Group Ltd (unless otherwise stated in the text of the article) 2017. All rights reserved. No commercial use is permitted unless otherwise expressly granted.

\section{REFERENCES}

1 Montagnese F, Wenninger S, Schoser B. "Orbiting around" the orbital myositis: clinical features, differential diagnosis and therapy. J Neurol 2016;263:631-40.

2 Schoser BG. Ocular myositis: diagnostic assessment, differential diagnoses, and therapy of a rare muscle disease-five new cases and review. Clin Ophthalmol 2007:1:37-42.

3 Ersoy A, Soyturk M. Idiopathic orbital myositis presenting as cluster headache: a case report. Acta Neurol Belg 2017.

Copyright 2017 BMJ Publishing Group. All rights reserved. For permission to reuse any of this content visit http://group.bmj.com/group/rights-licensing/permissions.

BMJ Case Report Fellows may re-use this article for personal use and teaching without any further permission.

Become a Fellow of BMJ Case Reports today and you can:

- Submit as many cases as you like

- Enjoy fast sympathetic peer review and rapid publication of accepted articles

- Access all the published articles

- Re-use any of the published material for personal use and teaching without further permission

For information on Institutional Fellowships contact consortiasales@bmjgroup.com

Visit casereports.bmj.com for more articles like this and to become a Fellow 